Hakan GEREN

Ece GÜRE
Ege Üniversitesi, Ziraat Fakültesi, Tarla Bitkileri Bölümü, 35100, İzmir / Türkiye

sorumlu yazar: hakan.geren@ege.edu.tr

Anahtar Sözcükler:

Chenopodium quinoa, $\mathrm{N}$ ve $\mathrm{P}$ seviyesi, tane verimi

Key Words:

Chenopodium quinoa, $\mathrm{N}$ and $\mathrm{P}$ levels, grain yield

\section{Farklı Azot ve Fosfor Seviyelerinin Kinoa (Chenopodium quinoa Willd.)'da Tane Verimi ve Bazı Verim Unsurlarına Etkisi Üzerinde Bir Ön Araştırma}

\author{
A Preliminary Study on the Effect of Different N and P Levels \\ on the Grain Yield and Other Yield Components of Quinoa \\ (Chenopodium quinoa Willd.)
}

Alınış (Received): 10.06.2016 Kabul tarihi (Accepted): 21.07.2016

\begin{abstract}
Q uinoa is a pseudo-cereal crop that has been cultivated for thousands of years in the Andean region in South America but it is a new introduction in Turkey. The quinoa as a field crop has a great potential in the improvement of food for humans and animals even under the conditions of marginal lands. For getting high crop yields, nutrients in balanced amount are a basic requirement. To evaluate the influence of different $N$ and $P$ levels on the productivity of quinoa, a pot experiment under outdoor condition was conducted on a quinoa genotype (Q-52) with four nitrogen $(0,100,150,200 \mathrm{~kg} / \mathrm{ha})$ and three phosphor levels $(0,50,100 \mathrm{~kg} / \mathrm{ha})$. Traits tested in the experiment were plant height, harvest index and grain yield. Results indicated that increasing $\mathbf{N}$ and $\mathrm{P}$ levels positively affected above mentioned traits compared to control, and the highest grain yield obtained from N150 and P100 application for quinoa.
\end{abstract}


karşılanmasında önemli rol üstlenebilmektedir (Doweidar ve Kamel, 2011; Tan ve Yöndem, 2013). Kinoa tohumu proteini, pek çok tahılda sınırlı olan özellikle methionin, threonin ve lysin gibi temel amino asitler bakımından oldukça zengindir (Bhargava ve ark., 2007; Comai ve ark., 2007). Kinoadan yapılan gıdaların NASA tarafından "Astronot Gıdası" olarak da isimlendirildiği ve kullanıldığı belirtilmiştir. Bu nedenle FAO (The Organization of the United Nations for Food and Agriculture) tarafından 2013, "Kinoa Yılı" olarak ilan edilmiştir (Anonim, 2013).

Türkiye'ye son on yıl içinde giriş yapan kinoa, Latin Amerika bölgesinin doğal bir bitkisi olup, geleneksel tahıl üretimiyle karşılaştırıldığında daha düşük girdili ve hastalıklara karşı daha dayanıklı bir bitkiyi temsil etmektedir (Rea ve ark., 1979; Basra ve ark., 2014). $\mathrm{Bu}$ nedenle bitkinin üretim teknikleri hakkında bilgi sahibi olabilmek sadece Türkiye için değil, yetişebileceği olası diğer ülkeler için de büyük bir önem taşımaktadır. Türkiye'de kinoa yetiştiriciliğiyle ilgili yapılan bazı çalışmalar, bu bitki ile ilgili daha ayrıntılı çalışmalar yapılması gerektiğini göstermiştir (Ince Kaya, 2010). Bu amaçla, Ağustos 2015 tarihinde, İstanbul'da "Kinoa Yetiştiricileri Derneği" kurulmuştur (Anonim, 2015).

Bilindiği gibi, bitkilerin birim alandan elde edilen biyokütle verimlerini yükseltmenin en etkili ve temel yollarında birisi, gübre ihtiyaçlarını optimum bir dozda ve zamanda karşılamaktan geçmektedir (Kacar ve Katkat, 1999). Azot, bitki gelişmesinde yaşamsal önemi olan bir bitki besin maddesidir. Bitki besin maddesi olarak azot, bitki bünyesinde azotlu bileşiklerin artmasına, çok yıllık bitkilerin erken uyanmasına, oluşan yaprakların daha iri, gevşek yapılı ve bol sulu olmalarına neden olur ki, bunun temel nedeni bitki bünyesindeki azotlu bileşiklerin su tutma özelliğinin fazla olmasıdır (Kacar, 1986). Ancak azotlu gübrelerin bu olumsuz etkisi potasyumlu gübrelerle giderilebilmektedir. Zira potasyum, bitki dokularının sağlamlaştırılmasına ve yapraklarda azot metabolizmasını dengeleyerek bitkide kuru madde artışına neden olabilmekte, bitkilerin soğuktan daha az zarar görmesini sağlayabilmektedir. Proteinlerin oluşmasındaki rollerinden başka azot, klorofil moleküllerinin yapılarında da yer almaktadır. Yeterince azotun sağlanmasıyla bitkiler koyu yeşil renkli, kuvvetli bir vejetatif gelişme göstermektedirler (Kacar, 1986; Kacar ve Katkat, 1999).

Fosfor bitkide çok önemli bazı organik bileşiklerin yapısında bulunmaktadır. Bitkide enerji transferi yapan ATP bu bileşiklerin en önemlilerindendir (Kacar, 1986; Kacar ve Katkat, 1999). Ayrıca fosfor karbonhidratların parçalanmasında, polisakkaritlerin bileşiminde de rol üstlenmekte ve bitkide genetik özellikleri belirleyen
DNA'nın oluşumu için de gereklidir. Fosfor, bitkinin generatif organlarında diğer organlara göre daha çok bulunmaktadır. Ayrıca fosfor bitkinin daha çok generatif gelişmesi üzerine etkili olan bir element olarak bilinmekte ve noksanlığında, çiçek, meyve, tohum gibi generatif organlar zarar görmektedir. Bununla birlikte fosfor noksanlığı bitkinin vejetatif gelişmesini de olumsuz etkilemekte ve büyüme gerilemektedir. Fosfor, bitki kök sisteminin gelişmesine katkıda bulunduğu gibi, çiçeklenme ve olgunlaşmayı da hızlandırmaktadır. Kurak bölgelerde fosfor $\mathrm{Ca}$, vb. elementlere bağlanabildiğinden bitkilerin yararlanamayacağı formlara dönüşebilmektedir. Bu nedenle bitkilere uygulanacak fosfor gübresinin ekimle birlikte ve tohuma yakın bir yere uygulanması gerekmektedir (Chapman ve Carter, 1976; Kacar, 1986; Kacar ve Katkat, 1999). Bitkiler gereksinim duydukları fosforun tamamına yakın bir bölümünü gelişmelerinin ilk dönemlerinde almakta ve bunu çeşitli organlarında biriktirmektedirler.

Göreceli olarak düşük verimli marjinal topraklarda başarıyla yetiştirilebilen kinoa (Jacobsen, 2003), topraktaki azota yüksek derecede tepki vermektedir (Erley ve ark., 2005; Gomaa, 2013). Mısır ekolojik koşullarında kinoa bitkisiyle çalışan Basra ve ark. (2014), dekara $7.5 \mathrm{~kg}$ uygulanan azotun bitki büyüme ve gelişmesiyle birlikte en yüksek tane veriminin alındığı en uygun $\mathrm{N}$ dozu olduğunu bildirmiştir. Carlsson ve ark. (1984) kinoa bitkisine dekara 15, 26, 47 ve 88 kg azot uyguladıkları bir çalışmada en yüksek kuru madde verimi ve protein içeriğinin $47 \mathrm{~kg} / \mathrm{da} \mathrm{N}$ uygulamasından alındığını bildirmişlerdir. Thanapornpoonpong (2004) tarafından 2001 ve 2002 yılında, Kuzey Almanya ekolojik koşullarında Genotip Faro ve Tango kinoa çeşitleri ile Barnkraft ve K432 isimli Amaranthus çeşitleri üzerinde yürütülen bir çalışmada, üç farklı azot $\left(\mathrm{NH}_{4} \mathrm{NO}_{3}\right)$ dozunun (0-0.8-1.2 $\mathrm{g} \mathrm{N} /$ saksı), bitki boyu, kuru biyokütle verimi ve tane verimi üzerine olan etkileri incelenmiştir. Verilen $\mathrm{N}$ seviyesi arttıkça kuru biyokütle verimi $(9,31$ ve $35 \mathrm{~g} / \mathrm{bitki})$ ve tane veriminin (2.2-7.2 ve $9.6 \mathrm{~g} /$ bitki) yükseldiğini bildiren araştırıcı, $\mathrm{N}$ seviyesi 0 $\mathrm{g} / \mathrm{saksıdan} 0.8 \mathrm{~g} / \mathrm{saksıya} \mathrm{doğru} \mathrm{arttıkça} \mathrm{bitki} \mathrm{boyunda}$ artış olduğunu (84 cm'den 114 cm'ye) fakat $1.2 \mathrm{~g}$ $\mathrm{N} /$ saksı dozunda bitki boyunun azaldığını $(111 \mathrm{~cm})$ belirtmiştir.

Samsun ekolojik koşullarında, horoz ibiği çeşitlerine (Amaranthus mategazzianus ve A.cruentus) farklı N dozları (0-3-6-9-12 kg/da) uygulanmış ve artan $\mathrm{N}$ dozlarının her iki çeşitte bitki boyu ve kuru ot veriminin artışına neden olduğunu (Genç ve Acar, 1999) fakat tohum verim ve bin tane ağırlıkları üzerine önemli etkisinin bulunmadığı (Acar, 1996) bildirilmiştir. 
Erley ve ark. (2005) tarafından 1994 ve 1995 yıllarında Güney Almanya ekolojik koşullarında yürütülen bir çalışmada, Faro ve Cochabamba isimli kinoa çeşitlerinde üç farklı azot $(0,8$ ve $12 \mathrm{~kg} / \mathrm{da})$ seviyesinin tane verimi ve hasat indeksi üzerindeki etkileri incelenmiştir. $\mathrm{N}$ dozu arttıkça dekara tane verimlerinin sırasıyla $179 \mathrm{~kg}, 308 \mathrm{~kg}$ ve $350 \mathrm{~kg}$ 'a yükseldiğini bildiren araştırıcılar, dekara $8 \mathrm{~kg}$ ile $12 \mathrm{~kg}$ $\mathrm{N}$ uygulamaları arasında önemli fark bulunmadığını, hasat indeksinin ise (ortalama \%31) N dozlarından etkilenmediğini fakat yıllar arasında önemli farklar bulunduğunu da belirtmişlerdir.

Bilalis ve ark. (2012) tarafından Agrinio/Batı Yunanistan ekolojik koşullarında yürütülen organik kinoa üretimi çalışmasında, hayvan gübresi (200 $\mathrm{kg} / \mathrm{da}, \% 1.24 \mathrm{~N}^{\prime} \mathrm{lu}$ ) ve deniz yosunu kompostunun (25 $\mathrm{kg} / \mathrm{da}, \% 8 \mathrm{~N}^{\prime} \mathrm{lu}$ ) tane verimi üzerindeki etkileri araştırılmıştır. Hayvan gübresi uygulamasının tane verimini kontrole göre ortalama \%11, kompost uygulamasının ise $\% 8$ yükselttiği bildiren araştırıcılar ortalama tane veriminin de $255 \mathrm{~kg} / \mathrm{da}$ olarak kaydedildiğini ifade etmişlerdir. Shams (2012) tarafından Mısır ekolojik koşullarında 2008-2010 yıllarında yürütülen bir çalışmada, Titicaca isimli kinoa çeşidinde, $7.14 \mathrm{~kg} / \mathrm{da} P$ sabit olmak üzere beş farklı $\mathrm{N}$ $(0,9,18,27$ ve $36 \mathrm{~kg} / \mathrm{da})$ seviyesinin verim ve bazı verim özelliklerine etkisi incelenmiştir. $\mathrm{N}$ dozlarının bitki boyu ve tane verimi ile biyolojik verim üzerine önemli etkilerinin bulunduğunu bildiren araştıııcı, her iki deneme yılında da bu özelliklere ait en yüksek değerlerin $36 \mathrm{~kg} / \mathrm{da} \mathrm{N}$ uygulamasından elde edildiğini saptamıştır.

Gomaa (2013) tarafından 2010-2012 yılları arasında Nobaria/Mısır ekolojik koşullarında yürütülen bir çalışmada, kinoaya iki değişik biyogübre (nitrobin ve fosforin) altında dört azot $(0,12,24,36 \mathrm{~kg} / \mathrm{da})$ ve dört fosfor $(0,12,24,36 \mathrm{~kg} / \mathrm{da})$ seviyesi uygulanarak tane verimi ve bazı verim özellikleri incelenmiştir. Araştırıcı, kontrol parsellerine göre; bitki boyu, tane verimi ve bin tane ağırlığı bakımından en yüksek değerlerin ilk yıl $24 \mathrm{~kg} / \mathrm{da} \mathrm{N}+$ nitrobin+12 kg/da $\mathrm{P}+$ fosforin, ikinci yıl $24 \mathrm{~kg} / \mathrm{da} \mathrm{N}+$ nitrobin+24 kg/da $\mathrm{P}+$ fosforin kombinasyonundan sağlandığını belirtmiştir.

Basra ve ark. (2014) tarafindan 2010 yılında Faisalabad/Pakistan ekolojik şartlarında yürütülen bir çalışmada, iki değişik kinoa genotipine (A9 ve $C P J-2)$ $6.5 \mathrm{~kg} / \mathrm{da} P$ sabit tutulmak üzere beş farklı $(0,5,7.5,10$ ve $12.5 \mathrm{~kg} / \mathrm{da}$ ) seviyede uygulanan azotun verim ve bazı verim özelliklerine etkileri araştırıımıştır. Çeşitler arasında çiçeklenme süresi bakımından önemli fark bulunmasına karşııık, N dozları arasında önemli farklılık bulunmadığını bildiren araştırıcılar, bitki boyu ve tane verimi üzerine $\mathrm{N}$ dozlarının önemli etkilerinin bulunduğunu ancak bin tane ağırlığı üzerinde bu etkinin önemsiz kaldığını bildirmişlerdir. En yüksek tohum verimlerinin CPJ-2 çeşidi için $7.5 \mathrm{~kg} / \mathrm{da} \mathrm{N}$, A9 çeşidi için ise $10 \mathrm{~kg} / \mathrm{da} \mathrm{N}$ seviyesinde kaydedildiğini bildiren araştırıcılar, $12.5 \mathrm{~kg} / \mathrm{da} \mathrm{N}$ seviyesinde her iki çeşitte de tane verimlerinin düştüğünü ifade etmişlerdir.

Kakabouki ve ark. (2014) tarafından 2012 yılında Agrinio/Batı Yunanistan ekolojik koşullarında yürütülen bir çalışmada, kinoa bitkisinde geleneksel ve azaltılmış toprak işleme altında hayvan gübresi ve mineral azot etkileri araştırılmıştır. Dekara 0, 10 ve $20 \mathrm{~kg}$ azot dozu ve hayvan gübresinin $(200 \mathrm{~kg} / \mathrm{da}, \% 1.24 \mathrm{~N})$ etkilerinin incelendiği çalışmada, kinoanın toprak işleme ve gübrelerden önemli derecede etkilendiği saptanmıştır. En yüksek ham protein veriminin geleneksel toprak işleme ve dekara $20 \mathrm{~kg} \mathrm{~N}$ uygulaması kombinasyonundan elde edildiğini bildiren araştırıcılar, ham kül oranının toprak işleme veya gübrelerden etkilenmediğini de vurgulamışlardır.

$\mathrm{Bu}$ çalışma; ülkemizde ve bölgemizde üreticiler tarafından henüz bilinmeyen ve yaygın olarak tarımı yapılmayan fakat ilerleyen zamanlarda yaygınlaşacağı düşünülen kinoa bitkisinde, farklı azot ve fosfor seviyelerinin tane verimi ve bazı verim unsurları üzerindeki etkilerini incelemek amacıyla yürütülmüştür.

\section{MATERYAL ve YÖNTEM}

Araştırma, 2012 yılı Mart-Temmuz ayları arasında, Ege Üniversitesi Ziraat Fakültesi Tarla Bitkileri Bölümü Bornova Deneme Tarlaları üzerinde (dış ortam) saksı denemesi şeklinde yürütülmüştür. Denemede, "Q-52" isimli kinoa (Chenopodium quinoa) çeşidi kullanıımıştır. Araştırma yerinin bazı iklim özellikleri Çizelge 1'de sunulmuştur. Saksı denemesinde kullanılan toprak İzmir'in Bayındır ilçesinden temin edilerek, Zeytincilik Araştırma Enstitüsü Toprak Analiz Laboratuarları'nda fiziksel ve kimyasal açıdan analiz edilmiş (Çizelge 2), toprak özellikleri bakımından kinoa bitkisinin yetişmesini kısıtlayıcı bir unsurun bulunmadığı tespit edilmiştir.

Çizelge 1. Araştırma yerinin bazı iklim özellikleri

Table 1. Some meteorological characteristics of experimental area

\begin{tabular}{lcccccc}
\hline & \multicolumn{2}{c}{ Hava Sıcaklığı $\left({ }^{\circ} \mathbf{C}\right)$} & \multicolumn{2}{c}{ Yağış $(\mathbf{m m})$} & \multicolumn{2}{c}{ Oransal nem (\%) } \\
\cline { 2 - 7 } Aylar & $\mathbf{2 0 1 2}$ & UYO & $\mathbf{2 0 1 2}$ & UYO & $\mathbf{2 0 1 2}$ & UYO \\
\hline Mart & 12.0 & 11.8 & 72.8 & 77.9 & 65 & 63 \\
Nisan & 16.2 & 15.9 & 43.4 & 46.7 & 63 & 61 \\
Mayıs & 20.5 & 20.9 & 39.0 & 25.8 & 60 & 58 \\
Haziran & 24.3 & 25.8 & 8.5 & 8.2 & 52 & 49 \\
Temmuz & 27.3 & 28.1 & 3.3 & 2.3 & 49 & 49 \\
\hline
\end{tabular}

UYO : Uzun Yıllar Ortalaması 
Çizelge 2. Deneme toprağının bazı fiziksel ve kimyasal özellikleri Table 2. Some physical and chemical characteristics of experimental soil

\begin{tabular}{lc|lc}
\hline \multicolumn{2}{l|}{ Özellikler } & & Özellikler \\
\hline Kum (\%) & 80.2 & Eriyebilir Toplam Tuz (\%) & 0.03 \\
Kil (\%) & 1.8 & Organik Madde (\%) & 2.27 \\
Mil (\%) & 18.0 & Toplam N (\%) & 0.092 \\
Bünye & tınlı kum & Faydalı P (ppm) & 2.54 \\
pH & 5.83 & Faydalı K (ppm) & 40 \\
Kireç (\%) & 0.82 & Faydalı Ca (ppm) & 1300 \\
\hline
\end{tabular}

Araştırmada iki faktör incelenmiş olup, bunlar; a) azot (0-5-10-15-20 kg/da) ve b) fosfor (0-5-10 kg/da) seviyesidir. İki faktörlü tesadüf parselleri deneme desenine göre 4 tekerrürlü olarak düzenlenen çalışmada toplam 60 saksı kullanılmıştır. $3 \mathrm{~mm}$ 'lik elekten geçirilen toprak, üst çapı $22 \mathrm{~cm}$, alt çapı $17 \mathrm{~cm}$, yüksekliği de $21 \mathrm{~cm}$ olan plastik saksıların her birine, üst kısmından $2 \mathrm{~cm}$ boşluk kalacak şekilde, $4.0 \mathrm{~kg}$ toprakla doldurulmuş ve saksıların tarla kapasiteleri hesaplanmıştır.

28 Mart 2012 tarihinde tohum ekimleri yapılmıştır. Ekimden önce her saksıya hesaplanan azot (üre) ve fosfor (triple süper fosfat) gübresi, ayrıca tüm saksılara (NO ve PO hariç) dekara $10 \mathrm{~kg}$ hesabıyla potasyum (potasyum sülfat) uygulanmıştır. Çıkışları garanti altına almak amacıyla her saksıya 5 adet tohum ekilmiş, çıkışlar tamamlanıp, bitkiler $15-20 \mathrm{~cm}$ boylandığında tekleme işlemi uygulanmıştır. Dış ortamdaki saksılar, yüksekliği $120 \mathrm{~cm}$, kenar uzunlukları $2 \mathrm{~m}$ olan kare şeklindeki bir kafesin içine konarak, olası zararlı (kuş, kedi, köpek, vb) saldırılarından korunmuştur. Ayrıca bu kafesin üst kısmı yağışı havalarda naylonla örtülerek deneme, yağışın olası etkilerinden korunmuştur.

Saksıların nem içeriği 3-4 günde bir dijital teraziyle tartılarak kontrol edilmiş, gerekli durumlarda saksının nem içeriği, çeşme suyuyla sulanarak tarla kapasitesine getirilmiş̧ir. Saksı içinde çıkan yabancı otlar elle temizlenmiştir. Herhangi bir hastalık veya zararlı etkisi gözlemlenmediği için kimyasal mücadele yapılmamıştır. Saksıdaki bitkiler tamamen kuruduğu, bir başka ifadeyle, bitkinin çiçek salkımı elle ovuşturulduğunda tanelerin avuç içine döküldüğü zamanda (Temmuz ortası, ortalama tane nemi \%13 nem) hasat işlemlerine başlanmıştır.

Çalışmada şu özellikler incelenmiştir (Bhargava ve ark.,2007 ve 2008): Çiçeklenme gün sayısı (gün): Çıkıştan itibaren \%50 çiçeklenmeye ulaşan bitkilerin geçirdiği gün sayıları kaydedilmiştir. Bitki boyu $(\mathrm{cm})$ : Toprak seviyesinden ana salkımın en uç noktasına kadar olan mesafe ölçülmüştür. Bin tane ağırlı̆̆ı (g): Yüz tohum içeren dört grubun ortalama ağırlığı belirlenmiş ve sonuç on ile çarpılmıştır. Hasat indeksi (\%): Bitki başına düşen tane ağırlığının, toprak üstü toplam kuru ağırlığa bölünmesiyle belirlenmiştir. Tane verimi ( $\mathrm{g} / \mathrm{bitki}$ ): Tek bitkiden elde edilen taneler harmanlandıktan sonra hassas teraziyle tartılmıştır. Kök kuru ağırlığı (g/bitki): Saksı içinde kalan kökler, hasattan sonra dikkatli bir şekilde çıkarılmış, topraklarından yıkanarak arıtılmış, kurutulmuş ve tartılmıştır. Çalışmadan elde edilen veriler iki faktörlü tesadüf parselleri deneme desenine uygun olarak varyans analizine tabi tutularak istatistiksel olarak (LSD, \%1) değerlendirilmiştir (Yurtsever, 1984).

\section{ARAŞTIRMA BULGULARI ve TARTIŞMA}

Çiçeklenme Gün Sayısı: P ve N'lu gübre seviyeleri ile PxN interaksiyonunun çiçeklenme gün sayısı üzerine önemli etkileri bulunmuştur (Çizelge 3). Rakamsal olarak en yüksek çiçeklenme gün sayısı 84.0 gün ile $\mathrm{PO}$ ve N20 uygulamasında, en düşük çiçeklenme gün sayısı ise 61.5 gün ile $\mathrm{P} 10$ ve No uygulamasından elde edilmiştir.

Çalışmamızda fosfor seviyesi yükseldikçe, bir başka ifadeyle $0 \mathrm{~kg} / \mathrm{da}$ 'dan $10 \mathrm{~kg} / \mathrm{da}$ 'a doğru gidildikçe çiçeklenme gün sayısının azaldığı, azot seviyesi azaldıkça da (20 kg/da'dan 0 kg/da'a) çiçeklenme gün sayısının yine düştüğü, diğer bir ifadeyle, kinoa bitkisinin çiçeklenme zamanının kısaldığı saptanmıştır. Bitkilere uygulanan $\mathrm{N}$ seviyeleri yükseldikçe, vejetatif aksamın ve kardeşlenmenin teşvik edildiği, birim alandaki sap sayısının arttığı, buna karşııı generatif döneme geçişin geciktiği pek çok araştırıcı tarafından vurgulanmıştır (Popišil ve ark., 2006; Kakabouki ve ark., 2014). Shahzad ve ark. (2014) ise kinoa çeşitleri arasında çiçeklenme gün sayısı bakımından önemli fark olmasına karşılık, uygulanan $\mathrm{N}$ seviyelerinin $(0,5,7.5,10,12.5 \mathrm{~kg} / \mathrm{da})$ yükselmesi durumunda çiçeklenme gün sayısı üzerine önemli etkisinin olmadığını bildirmişlerdir. Diğer taraftan birçok araştırıcının (Kacar, 1986; Kacar ve Katkat, 1999; Gomaa, 2013) artan fosfor seviyelerinde genel olarak bitkilerin daha kısa sürede çiçeklendiğini veya tersi ifadeyle, fosfor noksanlığında bitkilerin geç olgunlaştıklarını bildirmeleri, bulgularımızı doğrulamaktadır. 
Çizelge 3. Farklı $\mathrm{N}$ ve $\mathrm{P}$ seviyelerinin kinoada tane verimi ve bazı verim unsurlarına etkisi

Table 3. Effect of different $N$ and $P$ levels on the grain yield and some yield characteristics of quinoa

\begin{tabular}{|c|c|c|c|c|c|c|c|c|c|}
\hline & PO & P5 & P10 & Ort & P0 & & P5 & P10 & Ort \\
\hline & \multicolumn{4}{|c|}{------ Çiçeklenme gün sayısı ------- } & \multicolumn{5}{|c|}{------ Bitki boyu (cm) ------- } \\
\hline No & 70.5 & 64.5 & 61.5 & 65.5 & 49.3 & & 70.8 & 78.8 & 66.3 \\
\hline N5 & 72.5 & 68.5 & 66.5 & 69.2 & 69.5 & & 86.0 & 94.3 & 83.3 \\
\hline N10 & 79.5 & 75.5 & 71.5 & 75.5 & 70.0 & & 86.3 & 101.5 & 85.9 \\
\hline N15 & 83.0 & 76.5 & 74.5 & 78.0 & 84.5 & & 93.3 & 99.5 & 92.4 \\
\hline N20 & 84.0 & 77.5 & 74.5 & 78.7 & 77.8 & & 92.5 & 97.5 & 89.3 \\
\hline Ortalama & 77.9 & 72.5 & 69.7 & 73.4 & 70.2 & & 85.8 & 94.3 & 83.4 \\
\hline \multirow[t]{2}{*}{ LSD (\%1) } & $P: 0.52 \quad N: 0.67$ & PxN:1.17 & CV(\%):1.84 & & $P: 4.15$ & $\mathrm{~N}: 3.36$ & PxN:6.94 & CV(\%):5.84 & \\
\hline & \multicolumn{4}{|c|}{------- 1000 tane ağırlığı (g) ------- } & \multicolumn{5}{|c|}{----- Kök kuru ağırlığı (g/bitki) ----- } \\
\hline No & 2.19 & 2.71 & 3.38 & 2.76 & 12.1 & & 12.6 & 13.1 & 12.6 \\
\hline N5 & 2.24 & 2.73 & 3.34 & 2.77 & 13.7 & & 15.5 & 28.9 & 19.3 \\
\hline N10 & 2.29 & 2.88 & 3.28 & 2.82 & 15.2 & & 26.4 & 31.6 & 24.4 \\
\hline N15 & 2.27 & 3.00 & 3.13 & 2.80 & 15.5 & & 21.0 & 39.1 & 25.2 \\
\hline N20 & 2.28 & 3.00 & 3.12 & 2.80 & 16.0 & & 16.5 & 30.2 & 20.9 \\
\hline Ortalama & 2.25 & 2.86 & 3.25 & 2.79 & 14.5 & & 18.4 & 28.6 & 20.5 \\
\hline \multirow[t]{2}{*}{ LSD (\%1) } & P:0.048 N:ÖD & PxN:0.108 & CV(\%):2.03 & & $P: 2.66$ & $\mathrm{~N}: 3.44$ & PxN:5.96 & CV(\%):15.27 & \\
\hline & \multicolumn{4}{|c|}{---------- Hasat indeksi (\%) --------- } & \multicolumn{5}{|c|}{------ Tane verimi (g/bitki) ------ } \\
\hline No & 25.2 & 32.2 & 28.4 & 28.6 & 2.2 & & 3.4 & 4.8 & 3.5 \\
\hline N5 & 28.3 & 29.9 & 29.4 & 29.2 & 3.5 & & 4.9 & 6.2 & 4.9 \\
\hline N10 & 31.6 & 38.7 & 42.1 & 37.5 & 6.9 & & 8.1 & 9.5 & 8.2 \\
\hline N15 & 43.8 & 44.9 & 47.5 & 45.4 & 8.0 & & 10.4 & 12.5 & 10.3 \\
\hline N20 & 44.1 & 44.8 & 50.3 & 46.4 & 9.5 & & 10.1 & 12.1 & 10.6 \\
\hline Ortalama & 34.6 & 38.1 & 39.5 & 37.4 & 6.0 & & 7.4 & 9.0 & 7.5 \\
\hline LSD (\%1) & $\mathrm{P}: 2.40 \quad \mathrm{~N}: 3.10$ & PxN:5.37 & CV(\%):7.54 & & $P: 0.66$ & $\mathrm{~N}: 0.86$ & PxN:ÖD & CV(\%):10.41 & \\
\hline
\end{tabular}

ÖD: Önemli değil, CV: Varyasyon katsayısı

Bitki boyu: $P$ ve $N$ seviyeleri ile PxN interaksiyonunun bitki boyu üzerine önemli etkilerinin olduğunu saptanmıştır. En yüksek bitki boyu değeri $101.5 \mathrm{~cm}$ ile P10 ve N10 gübre uygulamasında belirlenirken onu istatistiki olarak aynı grupta yer alan P10-N15 $(99.5 \mathrm{~cm})$ ile P10-N20 $(97.5 \mathrm{~cm})$ gübre uygulamaları izlemiş, en düşük bitki boyu değeri ise $49.3 \mathrm{~cm}$ ile PO-NO kombinasyonundan elde edilmiştir (Çizelge 3). Bitki boyuna ilişkin bulgularımız genel olarak değerlendirildiğinde, $\mathrm{P}$ seviyesi arttıkça kinoa boylarının yükseldiği saptanmıştır. Bitkiye uygulanan $\mathrm{N}$ seviyesi de $0 \mathrm{~kg} / \mathrm{da}$ 'dan $15 \mathrm{~kg} / \mathrm{da}$ 'a yükseltildiğinde bitki boyunun arttığı, ancak bu dozdan sonra boylarda hafifçe bir kısalma olduğu kaydedilmiştir. Bitkilere uygulanan $\mathrm{N}$ seviyeleri yükseldikçe, vejetatif aksamın yani bitki boyunun arttığını, buna karşılık aşırı N dozlarının bitkilerde fitotoksik etkilere yol açtığı birçok araştırıcı tarafından belirtilmiştir (El-Behri ve ark.,1993; Popišil ve ark., 2006). Shams (2012) kinoada artan N seviyelerinin $(0,9,18,27,36 \mathrm{~kg} / \mathrm{da})$ bitki boyunu arttırdığını ve en yüksek boy değerinin $36 \mathrm{~kg} / \mathrm{da} N$ uygulamasından alındığını ifade ederken, Shahzad ve ark. (2014) ise kinoa çeşitleri arasında boy bakımından önemli fark olmasına karşılık, kontrolden sonra uygulanan azot seviyeleri arasında istatistiki bir fark olmadığını vurgulamışlardır. Gomaa (2013) kontrolden sonra dekara 12 veya $24 \mathrm{~kg}$ olarak uygulanan $\mathrm{P}$ seviyeleri arasında fark olmadığını, ancak $36 \mathrm{~kg} / \mathrm{da} P$ uygulamasında bitki boyunun kısaldığını bildirmiştir.

Bin tane ağırlığı: Analiz sonuçları, bin tane ağırlığı üzerine PxN interaksiyonunun önemli etkisinin bulunduğunu ancak $\mathrm{N}$ seviyesinin bireysel olarak önemli etkiye sahip olmadığını göstermiştir (Çizelge 3). Rakamsal olarak en yüksek bin tane ağırlığı 3.38 gram ile N0 ve $\mathrm{P} 10$ uygulamasından, rakamsal olarak en düşük bin tane ağırlığı ise 2.19 gram ile NO-PO uygulamasında kaydedilmiştir. Çalışmamızda artan fosfor seviyelerinin bin tane ağırlığını yükselttiği saptanırken, azot seviyeleri arasında istatistiki bir fark belirlenmemiştir.

Gomaa (2013) kinoaya uygulanan farklı N ve P seviyelerinin bin tane ağırlığı üzerine önemli etkilerinin bulunduğunu ve dekara $24 \mathrm{~kg} \mathrm{~N}$ ve $12 \mathrm{~kg} \mathrm{P}$ uygulamasının bin tane ağırlığını kontrole göre yükselttiğini ancak 12 ve $24 \mathrm{~kg} / \mathrm{da} P$ uygulaması arasında önemli fark olmadığını belirtmiştir. Basra ve ark. (2014) ise $6.5 \mathrm{~kg} / \mathrm{da} P$ sabit tutulmak üzere kinoya uyguladığı beş farklı azot $(0,5,7.5,10$ ve $12.5 \mathrm{~kg} / \mathrm{da})$ seviyesinin bin tane ağırlığı üzerinde önemli etkisinin 
olmadığını bildirmişlerdir. Diğer taraftan Koziol (1993), kinoada çeşide göre bin tane ağırlı̆ı̆ının $1.9 \mathrm{~g}$ ile $4.3 \mathrm{~g}$ arasında geniş bir dağılım gösterdiğini, Lindeboom (2005) sarı tohumlu kinoa çeşitlerinde bin tane ağırlığının $3.6 \mathrm{~g}$, beyaz renklilerde $4.1 \mathrm{~g}$ ve sarı-pembe çeşitlerde $3.6 \mathrm{~g}$ olduğunu, Ince Kaya (2010) ise Çukurova koşullarında kinoada bin tane ağırlığının 2.1$2.6 \mathrm{~g}$ arasında değiştiğini bildirmiştir. Çalışmamızda farklı $\mathrm{N}$ ve $\mathrm{P}$ seviyeleri altında kaydedilen bin tane ağırlığı 2.19 ile $3.38 \mathrm{~g}$ arasında değiştiğinden yukarıdaki araştırıcıların bildirdiği sınırlar içinde bulunmaktadır.

Kök kuru ağırlığı: İstatistiki analiz sonuçları, $\mathrm{P}$ ve $\mathrm{N}$ seviyeleri ile PxN interaksiyonunun kök ağırlı̆ı üzerine önemli etkilerinin olduğunu göstermiştir. Çizelge 3 incelendiğinde, en yüksek kök veriminin $39.1 \mathrm{~g} / \mathrm{bitki}$ ile $\mathrm{P} 10$ ve $\mathrm{N} 15$ uygulamasından, rakamsal olarak en düşük kök ağırlığının ise $12.1 \mathrm{~g} / \mathrm{bitki}$ ile PO-NO uygulamasından elde edildiği belirlenmiştir. Çalışmamızda, saksılara uygulanan fosfor seviyesi arttıkça yani, $0 \mathrm{~kg} / \mathrm{da}$ 'dan 10 kg/da'a doğru gidildikçe, kinoa bitkisinin kuru kök verimin yükseldiği saptanmıştır. Bilindiği gibi $P$ elementinin bitkilerde yaşamsal fonksiyonlar açısından enerji transferi için gerekli olduğu, $P$ eksikliğinde bitkinin hem toprak üstü hem de kök gelişiminin olumsuz yönde etkilendiği pek çok araştırııı tarafından dile getirilmiştir (Chapman ve Carter, 1976; Kacar, 1986; Kacar ve Katkat, 1999). Çalışmamızda özellikle N15-P10 kombinasyonunda saptanan kuru kök ağırlığının NO-PO uygulamasına göre üç katından daha fazla olması, bulgularımızın yukarıdaki araştııııların ifadeleriyle uyumlu olduğunu göstermektedir. Diğer taraftan N0'dan N15 seviyesine kadar artan azot dozunun kök ağırlığını yükselttiği (N10 ile N15 arasındaki fark önemli değil), ancak N20 seviyesinin kök ağırlığında bir azalmaya neden olduğu saptanmıştır. Geren ve Geren (2015) saksıda yetiştirilen kinoada bitki başına kök kuru ağırlığının uygulanan su kısıtlamasına bağlı olarak 9-22 g arasında değiştiğini bildirmeleri, rakamsal olarak bulgularımızın kısmen örtüşstüğünü göstermektedir.

Hasat indeksi: Yapılan analizler hasat indeksi üzerine PxN interaksiyonunun önemli etkisinin bulunduğunu ortaya çıkarmıştır (Çizelge 3). En yüksek hasat indeksi \%50.3 ile P10-N20 kombinasyonundan elde edilirken, onu istatistiksel olarak aynı grupta yer alan P10-N15 (\%47.5) ve P5-N15 (\%44.9) kombinasyonları izlemiştir. En düşük hasat indeksi ise \%25.2 ile PO-NO kombinasyonundan sağlanmıştır. Bulgularımız genel olarak değerlendirildiğinde, saksılara uygulanan azot ve fosfor seviyesi yükseldikçe hasat indeksinin de arttığı, ancak P5 ve P10 ile N15 ve N20 seviyeleri arasında istatistiki anlamda fark olmadığı saptanmıştır. Schutle ve ark. (2005) tarafından Güney Almanya ekolojisinde yetiştirilen farklı kinoa çeşitlerine uygulanan dekara 0,8 ve $12 \mathrm{~kg}$ $\mathrm{N}$ dozlarının, hasat indeksi üzerine önemli etkisinin olmadığını, ancak çeşitler arasında önemli farklar olduğunu bildirmişlerdir. Shahzad ve ark. (2014) kinoa çeşitleri arasında hasat indeksi bakımından önemli fark olmasına karşılık, dekara uygulanan $7.5,10$ ve $12.5 \mathrm{~kg}$ $\mathrm{N}$ arasında istatistiki bir farkın bulunmadığını bildirmişlerdir.

Bilindiği gibi hasat indeksi tarımsal araştırmalarda önemli bir seçim kriteridir. Nitekim Bertero ve ark. (2004) ve Bhargava ve ark. (2007 ve 2008), tane veriminin toplam biyolojik verime oran olarak elde edilmesi nedeniyle, hasat indeksinin farklı çevre koşullarından tane verimine göre daha az etkilenebileceğini, bu nedenle hasat indeksinin önemli bir seçim ölçütü olarak kullanılabileceğini ifade etmişlerdir. Bu nedenle çalışmamızda, hasat indeksi üzerine saksılara uygulanan $\mathrm{P} 5$ ve $\mathrm{P} 10$ seviyesi ile N15 ve N20 seviyeleri arasında istatistiki anlamda önemli bir fark ortaya çıkmaması, kinoa bitkisine yöre koşullarında dekara $5 \mathrm{~kg} \mathrm{P}$ ve $15 \mathrm{~kg} \mathrm{~N}$ uygulanması gerektiğine işaret etmektedir.

Tane verimi: Analiz sonuçları, PxN interaksiyonunun önemsiz ancak $P$ ve $N$ seviyelerinin tane verimi üzerine önemli etkilerinin olduğunu göstermiştir. Çizelge 3 incelendiğinde, $P$ seviyeleri arasında en yüksek tane verimi ortalama $9.0 \mathrm{~g} / \mathrm{bitki}$ ile $\mathrm{P} 10$, en düşük verim ise $2.2 \mathrm{~g} / \mathrm{bitki}$ ile $\mathrm{PO}$ uygulamasından sağlanmıştır. $\mathrm{N}$ seviyeleri arasında da en yüksek tane verimi ortalama $10.6 \mathrm{~g} / \mathrm{bitki}$ ile N2O uygulamasından alınırken, onu istatistiki olarak aynı grupta yer alan N15 (10.3 g/bitki) seviyesi izlemiş, en düşük verim ise ortalama $3.5 \mathrm{~g} / \mathrm{bitki} \quad \mathrm{NO}$ uygulamasından sağlanmıştır.

Kinoa tane verimlerine ilişkin bulgularımız toplu bir şekilde değerlendirildiğinde, saksılara uygulanan fosfor seviyesi $0 \mathrm{~kg} / \mathrm{da}$ 'dan $10 \mathrm{~kg} / \mathrm{da}$ 'a doğru arttıkça tane verimlerinin yükseldiği, benzer şekilde, uygulanan azot dozu da arttıkça, yani 0 kg/da'dan 20 $\mathrm{kg} / \mathrm{da}$ 'a çıkıldıkça tane verimlerinin yine yükseldiği, ancak N15 ile N20 seviyesi arasında önemli fark olmadığı belirlenmiştir. Diğer taraftan, N15-P10 seviyesinde gübre uygulanan saksılardan elde ettiğimiz tane veriminin, NO-PO uygulamasının yaklaşık altı katı olduğu da dikkati çekmiştir. Schutle ve ark. (2005) Güney Almanya ekolojisinde NO seviyesinde $179 \mathrm{~kg} / \mathrm{da}$ olan tane veriminin, N8'de $308 \mathrm{~kg} / \mathrm{da}, \mathrm{N} 12$ seviyesinde ise $350 \mathrm{~kg} /$ da'a çıktığını ancak, N8 ile N12 arasında istatistiki bir farkın olmadığını bildirmişlerdir. Benzer şekilde Erley ve ark. (2005)'da Güney Almanya 
koşullarında iki farklı kinoa çeşidinde üç farklı azot $(0,8$ ve $12 \mathrm{~kg} / \mathrm{da}$ ) seviyesini inceledikleri çalışmada, tane verimi yönünden dekara $8 \mathrm{~kg}$ ile $12 \mathrm{~kg} \mathrm{~N}$ uygulamaları arasında önemli fark bulunmadığını belirtmişlerdir.

Bilalis ve ark. (2012) ise Batı Yunanistan ekolojik koşullarında hayvan gübresi (200 kg/da, \%1.24 N'lu) uygulamasının tane verimini kontrole göre ortalama $\% 11$ oranında yükselterek ortalama $255 \mathrm{~kg} / \mathrm{da}$ ulaştığını ifade etmişlerdir. Shams (2012) ise Mısır ekolojik koşullarında Titicaca isimli kinoa çeşidinde, $7.14 \mathrm{~kg} / \mathrm{da} P$ sabit olmak üzere beş farklı $\mathrm{N}(0,9,18,27$ ve $36 \mathrm{~kg} / \mathrm{da})$ seviyesini incelediği çalışmasında, en yüksek tane verimin $36 \mathrm{~kg} / \mathrm{da} \mathrm{N}$ uygulamasından elde edildiğini bildirmiştir. Yine Nobaria/Mısır ekolojik koşullarında çalışan Gomaa (2013), kinoaya iki değişik biyogübre (nitrobin ve fosforin) uygulaması altında dört azot $(0$, $12,24,36 \mathrm{~kg} / \mathrm{da})$ ve dört fosfor $(0,12,24,36 \mathrm{~kg} / \mathrm{da})$ seviyesi uygulamış ve kontrol parsellerine göre en yüksek tane veriminin $24 \mathrm{~kg} / \mathrm{da} \mathrm{N}+$ nitrobin +12 veya 24 $\mathrm{kg} / \mathrm{da} \quad \mathrm{P}+$ fosforin kombinasyonundan sağlandığını belirtmiştir.

Faisalabad/Pakistan ekolojik şartlarında çalışan Basra ve ark. (2014) ise en yüksek tane veriminin dekara $6.5 \mathrm{~kg}$ fosfor uygulaması sabit olmak üzere, CPJ-2 çeşidi için $7.5 \mathrm{~kg} / \mathrm{da} \mathrm{N}$, A9 çeşidi için ise $10 \mathrm{~kg} / \mathrm{da} \mathrm{N}$ seviyesinde kaydedildiğini bildirmişler ve $12.5 \mathrm{~kg} / \mathrm{da} \mathrm{N}$ seviyesinde her iki çeşitte tane verimlerinin düştüğünü ifade etmişlerdir. Bu

\section{KAYNAKLAR}

Acar, Z. 1996. İki yemlik horoz ibiği çeşidinin verimi ve bazı özelliklerine farklı azot dozlarının etkileri üzerine bir araştırma I.Tohum Verimi, O.M.Ü.Z.F. Dergisi, 11(2):187-196.

Anonim. 2013. Ana tahıl: Kinoa, Tübitak Bilim ve Teknik Dergisi, Haziran 2013, 547:34-35.

Anonim. 2015. Kinoa Yetiştiricileri Derneği (www.tukiyed.gov).

Basra, S.M.A., S.Iqbal and I.Afzal. 2014. Evaluating the response of nitrogen application on growth, development and yield of quinoa genotypes, International Journal of Agriculture \& Biology, 16(5):886-892.

Bertero, H.D., A.J.de la Vega, G.Correa, S.E.Jacobsen and A.Mujica. 2004. Genotype and genotype-by-environment interaction effects for grain yield and grain size of quinoa (Chenopodium quinoa Willd.) as revealed by pattern analysis of international multi-environment trials, Field Crops Research, 89:299-318.

Bhargava, A., S.Shukla and D.Ohri. 2007. Genetic variability and interrelationship among various morphological and quality traits in quinoa (Chenopodium quinoa Willd.), Field Crops Research, 101:104-116.

Bhargava, A., S.Shukla and D.Ohri. 2008. Genotype x environment interaction studies in Chenopodium album L.: an underutilized crop with promising potential, Communications in Biometry and Crop Science, 3(1):3-15. sonuçlardan da anlaşılacağı üzere; farklı ekolojilerde değişik kinoa çeşitlerinin azot ve fosfor seviyelerine farklı tepkiler verdiği görülmektedir. Özellikle P10 seviyesi altında N15 uygulamasında en yüksek tane verimi belirlenirken, $\mathrm{N} 20$ uygulamasında tane veriminin önemli olmayan düzeyde azalması bir kırılma noktası olarak değerlendirilmiş ve yöre ekolojik koşullarında yetiştirilen kinoa bitkisi için optimum gübre dozları olarak yorumlanmıştır. Çalışmamızın hasat indeksine ilişkin kısmından elde ettiğimiz bulgular da bu yorumumuzu desteklemektedir.

\section{SONUÇ ve ÖNERILER}

Ege bölgesinin, tipik Akdeniz iklimi etkisi altındaki dış ortam koşullarında saksı denemesi şeklinde yürütülen bu ön çalışmamızda, farklı azot $(0,5,10,15$, $20 \mathrm{~kg} / \mathrm{da})$ ve fosfor $(0,5,10 \mathrm{~kg} / \mathrm{da})$ seviyelerinde yetiştirilen kinoa (Chenopodium quinoa Willd.) bitkisinin "Q-52" çeşidinde, incelenen gübre seviyelerinin tane verimi ve diğer verim unsurları üzerinde önemli etkileri saptanmış, en yüksek tane verimi dekara $15 \mathrm{~kg} \mathrm{~N}$ ve $10 \mathrm{~kg} P$ uygulamasından elde edilmiştir. Bir ön çalışma niteliğinde elde edilen bu sonuçların, tarla çalışmalarıyla en az iki yıl süreyle test edilmesi, yeni çeşitlerin devreye sokularak detaylı çalışmalarla (örneğin artan fosfor seviyeleri) incelenmesi, daha güvenilir sonuçların alınmasına neden olacağı kanaatine de varılmıştır.

Bilalis, D., I.Kakabouki, A.Karkanis, I.Travlos, V.Triantafyllidis and D.Hela. 2012. Seed and saponin production of organic quinoa (Chenopodium quinoa Willd.) for different tillage and fertilization, Not. Bot. Horti. Agrobo., 40(1):42-46.

Carlsson, R., P.Hanczakowski and T.Kaptur. 1984. The quality of the green fraction of leaf protein concentrate from Chenopodium quinoa Willd. grown at different levels of fertilizer nitrogen, Animal Feed Science and Technology, 11(4):239-245.

Chapman, S.R. and L.P.Carter, 1976, Crop Production Principles and Practices, W. H. Freeman and Company, Sanfransisco, USA.

Comai, S., A.Bertazzo, L.Bailoni, M.Zancato, C.V.L.Costa and G.Allegri. 2007. The content of proteic and nonproteic (free and protein bound) tryptophan in quinoa and cereal flours, Food Chem. 100:1350-1355.

Doweidar, M.M. and A.S.Kamel. 2011. Using of quinoa for production of some bakery products (gluten-free), Egyptian J. Nutrition, 26(2):21-52.

El-Behri, A., D.H. Patnam and M. Schitt (1993). Nitrogen fertilizer and cultivar effects on yield and nitrogen use efficiency of grain amaranth Agron. J. 85, 120-128.

Erley, G.S., H.P.Kaul, M.Kruse and W.Aufhammer. 2005. Yield and nitrogen utilization efficiency of the pseudocereals amaranth, 
quinoa, and buckwheat under differing nitrogen fertilization, European Journal of Agronomy. 22 (1): 95-100.

Genç, N. ve Z.Acar. 1999. Horoz ibiği (Amaranthus sp.)'nin azot ihtiyacının ot ve tohum veriminin ve bazı özelliklerinin belirlenmesi üzerine bir araştırma, O.M.Ü.Z.F. Dergisi, 14(3):65-75

Geren, H. and H.Geren, 2015, A preliminary study on the effect of different irrigation water levels on the grain yield and related characteristics of quinoa (Chenopodium quinoa Willd.), $26^{\text {th }}$ International Scientific-Expert Conference of Agriculture and Food Industry, Sarajevo, 27-30 September 2015, Book of Abctracts, p:129.

Gomaa, E.F. 2013. Effect of nitrogen, phosphorus and biofertilizers on quinoa plant, Journal of Applied Sciences Research, 9(8):5210-5222

Ince Kaya, Ç. 2010. Effects of various irrigation strategies using fresh and saline water applied with drip irrigation system on yield of quinoa and salt accumulation in soil in the Mediterranean region and evaluation of saltmed model, MSc. Thesis, Çukurova Univ., Inst. of Natural and Applied Sci., Dept. of Agricultural Structures and Irrigation, $122 \mathrm{p}$.

Jacobsen, S.E. 2003. The worldwide potential for quinoa (Chenopodium quinoa Willd.). Food Rev Int, 19(1-2):167-177

Kacar, B. ve V.Katkat. 1999. Gübreler ve Gübreleme Tekniği. Uludağ Üniversitesi Güçlendirme Vakfı Yayın No: 144, Vipaş Yayin No:20, 531s., Bursa

Kacar, B. 1986. Gübreler ve Gübreleme Tekniği (III. Basım), T.C. Ziraat Bankası Kültür Yayınları No:20, Ankara, 439s.

Kakabouki, I., D.Bilalis, A.Karkanis, G.Zervas, E.Tsiplakou and D.Hela. 2014. Effects of fertilization and tillage system on growth and crude protein content of quinoa (Chenopodium quinoa Willd.): An alternative forage crop, Emir. J. Food Agric., 26(1):18-24.

Koziol, M.J. 1993. Quinoa: a potential new oil crop. In: New Crops. J.Janick and J.E.Simon (Eds.), Wiley, New York:328-336.
Lindeboom, N. 2005. Studies on the characterization, biosynthesis and isolation of starch and protein from quinoa (Chenopodium quinoa Willd.), University of Saskatchewan, Department of Applied Microbiology and Food Science, Ph.D. thesis, 152p.

Pospišil, A., M.Pospišil, B.Varga and Z.Svečnjak (2006). Grain yield and protein concentration of two amaranth species as influenced by nitrogen fertilization. Europ. J. Agron., 25 (3): 250-253.

Rea, J., M.Tapia and A.Mujica. 1979. Prácticas agronómicas. In: Quinoa y Kaňiwa, Cultivos Andinos, pp:83-120. Tapia,M. H.Gandarillas, S.Alandia, A.Cardozo and A.Mujica. (eds.). FAO, Rome, Italy.

Schulte, A.E.G., H.P.Kaul, M.Kruse and W.Aufhammer. 2005. Yield and nitrogen utilization efficiency of the pseudocereals amaranth, quinoa, and buckwheat under differing nitrogen fertilization. European Journal of Agronomy. 22 (1): 95-100.

Shahzad, M.A.B., S.Iqbal and I.Afzal. 2014. Evaluating the response of nitrogen application on growth, development and yield of quinoa genotypes, International Journal of Agriculture \& Biology, 16(5):886-892.

Shams, A.S. 2012. Response of quinoa to nitrogen fertilizer rates under sandy soil conditions, Proc. $13^{\text {th }}$ International Conf. Agron., Fac.of Agric., Benha Univ., Egypt, 9-10 September 2012, p:195-205

Tan, M ve Z.Yöndem. 2013. İnsan ve Hayvan Beslenmesinde Yen Bir Bitki: Kinoa (Chenopodium quinoa Willd.), Alınteri Zirai Bilimler Dergisi, 25(2):62-66.

Thanapornpoonpong, S. 2004. Effect of nitrogen fertilizer on nitrogen assimilation and seed quality of amaranth (Amaranthus spp.) and quinoa (Chenopodium quinoa Willd), Doctoral Dissertation, Doctor of Agricultural Sciences of the Faculty of Agricultural Sciences, Institute of Agricultural Chemistry, Georg-August-University of Göttingen.

Yurtsever, N. 1984. Deneysel İstatistik Metotlar, Toprak ve Gübre Araş.Enstitüsü Yayınları No:121, Ankara. 